\section{Cross-sectional study of epidemiology of congenital anomaly of the hand in a tertiary care centre in India over 1 year}

Sir,

Congenital hand anomalies, although rare, incur significantly physical and psychological trauma. Timely diagnosis and appropriate treatment can change the future of the child. Therefore, it is essential for treating doctor to refer these children to appropriate specialists.

The aim of this study is to know the epidemiology of such anomalies at our centre over a 1-year period, i.e. to know the most common diagnosis, risk factors and associated anomalies.

This study includes patients of congenital hand anomalies who had come to our OPD in the last 1 year, i.e. from $1^{\text {st }}$ September 2015 to $31^{\text {st }}$ August 2016. A total of 80 patients were seen, of those, 59 were new and 21 had come for follow-up. Forty-two were female patients and 38 were males. Mean age of the patients was 33.8 months, with eldest being 13 years and youngest being 10 days. Sixty-six patients were Hindus, 13 Muslims and 1 Christian. Four patients were born out of consanguinous marriage ( $4^{\text {th }}$ degree).

Mean age of mothers at the time of birth was 24.7 years. Forty-eight children were the first issue of their parents, 26 were the second issue, 5 were the third issue and 1 was the fourth issue. One pair of twins was noted. Higher incidence of anomalies in primipara was also noted in the study by Ghorpade et al. ${ }^{[1]}$ Forty-three children were born as full-term vaginal delivery, while rest had delivered by caesarean section. In the study by Ghorpade et al., rate of caesarean delivery was $44 \%$ which in India is just $8.5 \% .^{[1,2]}$ Thirty-four patients had birth weight $\leq 2.5 \mathrm{~kg}$.

Ratio of bilateral hand involvement to right to left side is 5:1.6:1. Among all congenital anomalies, syndactyly was most common (31 cases). Next common was radial club hand [Table 1]. This is in contrast to studies done in the United States in a mid-Western Centre and at Ludhiana (India) where polydactyly is the most common, followed by syndactyly [Figures 1 and 2]..$^{[1,3]}$

The most common associated anomalies in our series included Apert syndrome, Poland syndrome and isolated cleft palate. All associated anomalies are listed in Table 2. Vasluian et al. in their study done in Northern Netherland showed Patau syndrome to be the most common chromosomal anomaly while arthrogryposis was common among single gene anomalies. Cardiovascular system was most commonly affected. ${ }^{[4]}$

Forty-eight patients were operated among eighty patients in the last 1 year. The limitation of our study includes small sample size; therefore, the results may not

Table 1: Type of congenital hand anomaly

\begin{tabular}{lc}
\hline Type of anomaly & Number of patients \\
\hline Syndactyly & 31 \\
RCH & 18 \\
Transverse arrest & 6 \\
Constriction ring syndrome & 6 \\
Camptodactyly & 6 \\
Polydactyly/duplication & 6 \\
Cleft hand & 4 \\
Windblown hand & 1 \\
Brachydactyly & 1 \\
Lymphangioma & 1 \\
Macrodactyly & 1 \\
Radioulnar synostosis & 1 \\
\hline RCH: Radial club hand &
\end{tabular}

$\mathrm{RCH}$ : Radial club hand

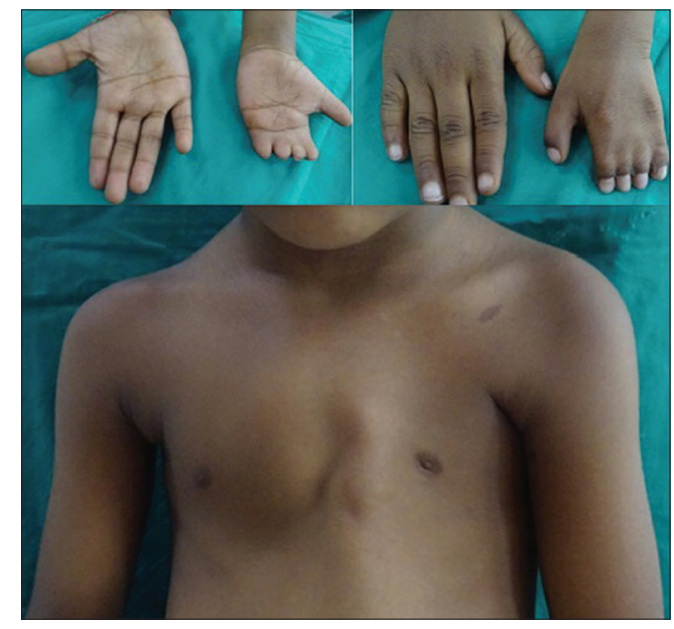

Figure 1: Case of Poland syndrome with left symbrachydactyly 
Table 2: Type of associated anomaly

\begin{tabular}{llc}
\hline Type of associated anomaly & Type of hand anomaly & Number of patients \\
\hline Apert syndrome & Apert hand (rose bud and mitten type) & 6 \\
Poland syndrome & $\mathrm{U} / \mathrm{L}$ symbrachydactyly & 3 \\
Pierre Robin sequence & $\mathrm{U} / \mathrm{L}$ brachydactyly, camptodactyly & 2 \\
Isolated cleft palate & Camptodactyly, syndactyly, RCH & 4 \\
Cleft lip and palate & $\mathrm{B} / \mathrm{L} \mathrm{RCH}$, cleft hand & 2 \\
CTEV & $\mathrm{Camptodactyly,} \mathrm{windblown} \mathrm{hand}$ & 3 \\
Congenital heart disease & $\mathrm{RCH}$, camptodactyly & 4 \\
Microtia & $\mathrm{B} / \mathrm{L}$ transverse arrest with right humeroulnar synostosis \\
Torticollis & Right RCH & 1 \\
Congenital diaphragmatic hernia & Right RCH & 1 \\
Inguinal hernia & Windblown hand & 1 \\
Hypospadias & $\mathrm{B} / \mathrm{L} \mathrm{symbrachydactyly}$ & 1 \\
VACTERL anomaly & $\mathrm{B} / \mathrm{L} \mathrm{RCH}$ & 1 \\
Meningomyelocele & $\mathrm{RCH}$ & 1 \\
\hline
\end{tabular}

CTEV: Congenital talipes equinovarus, U/L: Unilateral, B/L: Bilateral, RCH: Radial club hand

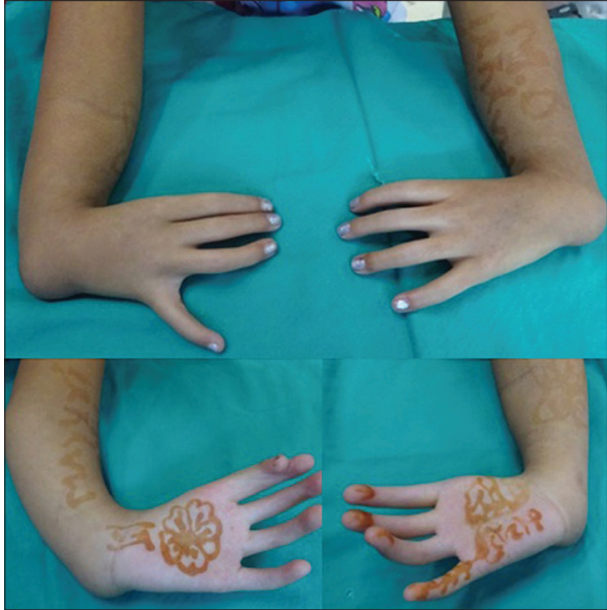

Figure 2: Case of bilateral radial club hand

be applicable to large population. This study however is still an interesting cross-sectional data of consecutive cases over a 1-year period.

\section{Financial support and sponsorship \\ Nil.}

\section{Conflicts of interest}

There are no conflicts of interest.

\section{Nikunj B. Mody, Shankar Srinivasan, Mukund Thatte}

Department of Burns and Plastic Surgery, B.J. Wadia Hospital for Children, Mumbai, Maharashtra, India

Address for correspondence: Dr. Mukund Thatte, Burns Research Unit, B.J. Wadia Hospital, Acharya Donde Marg, Lower Parel, Mumbai - 400 012, Maharashtra, India.

E-mail:mthatte@gmail.com

\section{REFERENCES}

1. Ghorpade N, Goyal N, John J. Prevalence of musculoskeletal abnormalities in newborn: A 10 years retrospective analysis of 10,674 neonates in Indian population at a tertiary care hospital. J Clin Neonatol 2015;4:104-8.

2. Gibbons L, Belizán JM, Lauer JA, Betran AP, Merialdi M, Althabe F. The Global Numbers and Costs of Additionally Needed and Unnecessary Caesarean Sections Performed per Year: Overuse as a Barrier to Universal Coverage. World Health Report, Background Paper, No. 30; 2010.

3. Goldfarb CA, Wall LB, Bohn DC, Moen P, Van Heest AE. Epidemiology of congenital upper limb anomalies in a Midwest United States population: An assessment using the Oberg, Manske, and Tonkin classification. J Hand Surg Am 2015;40:127-32.e1-2.

4. Vasluian E, van der Sluis CK, van Essen AJ, Bergman JE, Dijkstra PU, Reinders-Messelink HA, et al. Birth prevalence for congenital limb defects in the Northern Netherlands: A 30-year population-based study. BMC Musculoskelet Disord 2013;14:323.

This is an open access article distributed under the terms of the Creative Commons Attribution-NonCommercial-ShareAlike 3.0 License, which allows others to remix, tweak, and build upon the work non-commercially, as long as the author is credited and the new creations are licensed under the identical terms.

\begin{tabular}{|l|l|}
\hline \multicolumn{2}{|c|}{ Access this article online } \\
\hline Quick Response Code: & Website: \\
\hline & www.ijps.org \\
\cline { 2 - 2 } & DOI: \\
\hline
\end{tabular}

How to cite this article: Mody NB, Srinivasan S, Thatte M. Crosssectional study of epidemiology of congenital anomaly of the hand in a tertiary care centre in India over 1 year. Indian J Plast Surg 2016;49:424-5.

๔ 2016 Indian Journal of Plastic Surgery | Published by Wolters Kluwer - Medknow 